\title{
Pemilihan Portofolio Saham dengan Menggunakan Weighted Frequent Itemsets
}

\author{
Resi Annisa Nur ${ }^{\# 1}$, Deni Saepudin ${ }^{\# 2}$, Rian Febrian Umbara ${ }^{\# 3}$ \\ \# School of Computing, Universitas Telkom \\ Jalan Telekomunikasi No. 1 Terusan Buah Batu, Bandung 40257, Indonesia \\ ${ }^{1}$ resiannisanur@students.telkomuniversity.ac.ic \\ 2 denisaepudin@telkomuniversity.ac.id \\ ${ }^{3}$ rainum@telkomuniversity.ac.id
}

\begin{abstract}
The stock portfolio is a collection of shares owned by various sectors to be a proof of ownership of investors. These shares have different amounts of proportion. The purpose of this study is to create a stock portfolio by selecting stock itemsets that meet the requirements, namely minimum return and minimum diversification. This research uses data mining algorithm approach that is weighted frequent itemsets. Weighted frequent itemsets are stock data separation techniques that aim to find a relationship or correlation on a set of datasets to be selected. The dataset used for stock portfolio selection is taken from Yahoo Fianace (2018), the data used is taken from January 1, 2008 to December 31, 2017. Testing is done by setting a minimum return of $3 \%, 4 \%, 5 \%$. For selected itemsets of stock, it consists of many stocks that exceed the minimum return and diversified in different sectors. From the results of tests conducted, based on the performance of stock portfolio obtained stock return exceeds the stock price movement JCI (Composite Stock Price Index) based on the scenario periodically by using updated data.
\end{abstract}

Keywords: diversification, stock portfolio, weighted frequent itemsets.

Abstrak

Portofolio saham merupakan sekumpulan saham yang dimiliki oleh berbagai sektor untuk menjadi bukti kepemilikan para investor. Saham tersebut memiliki jumlah proporsi yang berbeda. Tujuan dari penelitian ini adalah untuk membuat sebuah portofolio saham dengan memilih itemsets saham yang memenuhi persyaratan, yaitu minimum return dan minimum diversifikasi. Penelitian ini menggunakan pendekatan algoritma data mining yaitu weighted frequent itemsets. Weighted frequent itemsets merupakan teknik pemisahan data saham yang bertujuan untuk menemukan hubungan atau korelasi pada sekumpulan dataset yang akan dipilih. Dataset yang digunakan untuk pemilihan portofolio saham diambil dari Yahoo Fianace (2018), data yang digunakan diambil dari Tanggal 1 Januari 2008 hingga 31 Desember 2017. Pengujian yang dilakukan yaitu dengan menetapkan minimum return 3\%, 4\%, 5\%. Untuk itemsets saham yang dipilih, terdiri dari banyak saham yang melebihi minimum return dan terdiversifikasi pada sektorsektor yang berbeda. Dari hasil pengujian yang dilakukan, berdasarkan kinerja portofolio saham yang diperoleh return saham melebihi pergerakan harga saham IHSG (Indeks Harga Saham Gabungan) berdasarkan skenario secara periodik dengan menggunakan data yang diupdate.

Kata kunci : diversifikasi, portofolio saham, weighted frequent itemsets. 
Resi Annisa Nur et.al.

Pemilihan Portofolio Saham dengan...

\section{PENDAhUluan}

$\mathbf{S}^{\mathrm{a}}$ ham merupakan surat berharga yang berisikan sekumpulan pembukuan data historis saham yang menjadi alah satu kepemilikan suatu perusahaan dan investor. Maka dari itu dilakukan pemilihan portofolio saham dengan cara menentukan itemsets saham yang akan dipilih dengan memaksimumkan return portofolio dan terdiversifikasi pada sektor-sektor yang berbeda. Return portofolio ini sangat dipengaruhi oleh naik turunya harga saham. Kemudian diversifikasi bertujuan untuk mendapatkan portofolio saham yang berada pada sektor yang berbeda.

Untuk dapat menentukan pemilihan itemsets saham yang akan dibuat portofolio, hal yang pertama dilakukan yaitu dengan menyiapkan dataset saham yang akan dianalisis. Kumpulan dataset ini dipilih dengan menggunakan pendekatan algoritma data mining yaitu, Weighted Frequent Itemsets. Weighted Frequent Itemsets merupakan teknik pemisahan data saham yang bertujuan untuk menemukan hubungan atau korelasi pada sekumpulan dataset yang akan dipilih [3].

Jadi, pada setiap dataset saham yang akan digunakan untuk pemilihan portofolio saham yaitu terdiri dari saham dan return. Kemudian dari hasil tersebut dapat direkomendasikan kepada investor untuk pembelian, penahanan, dan penjualan saham.

Elena Baralis, Luca Cagliero, Paolo Garza pada tahun 2017 melakukan perencanaan pembelian saham yang akan direkomendasikan kepada investor supaya dapat membatasi kerugian [3] . Pendekatan yang digunakan yaitu algoritma data mining, Weighted Frequent Itemsets. Dataset yang digunakan yaitu diambil dari NASDAQ-100 dan Dow Jones dengan minimum return 8\%, diversifikasi 70\% dan sebanyak 18 data saham. Sehingga pada penelitian ini dilakukan perbandingan dengan menggunakan data dari Yahoo! Finance (YahooFinance, 2018) dengan minimum return yang ditetapkan 3\%, 4\%, 5\%, diversifikasi 75\% dan sebanyak 27 data saham.

Pada pemilihan portofolio saham ini, untuk dataset saham didapatkan dari Yahoo! Finance (YahooFinance, 2018). Yahoo Finance ini menyediakan dataset saham dari berbagai perusahaan yang sudah terdaftar didalamnya. Kemudian untuk data sektor-sektor pasar diambil dari Bursa Efek Indonesia (BEI). Tujuan yang dilakukan yaitu mengimplementasikan Weighted Frequent Itemsets untuk memperoleh itemsets yang memenuhi minimum return dan terdiversifikasi pada sektor yang berbeda. Kemudian dapat mengetahui kinerja dari portofolio saham yang terpilih dan hasil perbandingan dengan IHSG.

\section{TINJAUAN PUSTAKA}

\section{A. Portofolio Saham}

Portofolio saham merupakan modal utama untuk seorang investor yang akan melakukan investasi. Portofolio saham ini terdiri dari berbagai saham yang dimiliki oleh berbagai sektor untuk menjadi bukti kepemilikan para investor. Bila salah satu dari saham tersebut mengalami penurunan harga, kemudian pada saham yang lain mengalami peningkatan, maka investasi yang dilakukan tidak akan mengalami kerugian [1] . Dalam pembelian saham, investor berhak untuk mendapatkan keuntungan atas pembelian yang sudah dilakukan.

\section{B. Weighted Frequent Itemsets}

Pemilihan saham untuk membuat portofolio ini menggunakan pendekatan algoritma data mining, yaitu Weighted Frequent Itemsets. Weighted Frequent Itemsets merupakan teknik pemisahan data saham yang bertujuan untuk menemukan hubungan atau korelasi pada sekumpulan dataset yang akan dipilih. Selain itu bisa menentukan bobot yang berbeda pada suatu item [2]. Portofolio saham yang dipilih terdiri dari item, item adalah jumlah dari berapa banyaknya jenis saham. Kemudian untuk itemsets mewakili kumpulan saham yang disebut portofolio. 


\section{Return Saham}

Return saham merupakan sesuatu hasil yang didapatkan dari selisih perhitungan harga saham. Untuk rumus yang digunakan untuk menghitung return yaitu sebagai berikut [10] :

$$
R_{t}=\frac{P_{t}-P_{t-1}}{P_{t-1}}
$$

Keterangan :

$R_{t}=$ Return saham pada saat $\mathrm{t}$.

$P_{t}=$ Harga saham pada saat $\mathrm{t}$.

$P_{t-1}=$ Harga saham pada saat $\mathrm{t}-1$.

\section{Weighted Stock Dataset}

Weighted Stock Dataset merupakan sekumpulan dataset saham yang digunakan untuk melakukan pemilihan portofolio saham yang memiliki nilai return. Jadi, satu set item saham terdiri dari saham dan return.

Tabel I. Dataset saham yang memiliki return.

\begin{tabular}{|c|c|c|c|c|c|c|c|c|c|c|}
\hline $\begin{array}{c}\text { Wakt } \\
\mathrm{u}\end{array}$ & BBNI & SMGR & INCI & APLI & ADES & MRAT & GGRM & SCMA & DNET & BAYU \\
\hline $\begin{array}{l}1 \mathrm{Jul} \\
2012 \\
\end{array}$ & $\begin{array}{c}- \\
0.00109\end{array}$ & $\begin{array}{c}0.23121 \\
4 \\
\end{array}$ & 0.14902 & $\begin{array}{c}- \\
0.04554\end{array}$ & 0.36164 & $\begin{array}{c}- \\
0.05523 \\
\end{array}$ & $\begin{array}{c}- \\
0.09517 \\
\end{array}$ & $\begin{array}{c}0.17971 \\
7 \\
\end{array}$ & $\begin{array}{c}- \\
0.11348 \\
\end{array}$ & $\begin{array}{c}0.12238 \\
8 \\
\end{array}$ \\
\hline $\begin{array}{l}2 \text { Jan } \\
2012\end{array}$ & $\begin{array}{c}- \\
04075\end{array}$ & $\begin{array}{c}0.21297 \\
1\end{array}$ & - & $\begin{array}{c}- \\
0.09852\end{array}$ & $\begin{array}{c}- \\
0.01014\end{array}$ & 0.10789 & $\begin{array}{c}- \\
0.00131\end{array}$ & $\begin{array}{c}0.31513 \\
6\end{array}$ & $\begin{array}{c}- \\
0.11875\end{array}$ & $\begin{array}{c}0.09477 \\
1\end{array}$ \\
\hline $\begin{array}{l}1 \mathrm{Jul} \\
2011\end{array}$ & $\begin{array}{c}0.06097 \\
6\end{array}$ & $\begin{array}{c}0.05064 \\
5\end{array}$ & -0.1442 & $\begin{array}{c}- \\
0.24442\end{array}$ & $\begin{array}{c}- \\
0.12325\end{array}$ & $\begin{array}{c}0.00485 \\
4\end{array}$ & $\begin{array}{c}0.37840 \\
5\end{array}$ & $\begin{array}{c}0.54110 \\
9\end{array}$ & 0 & $\begin{array}{c}0.00657 \\
9\end{array}$ \\
\hline $\begin{array}{l}2 \text { Jan } \\
2011 \\
\end{array}$ & $\begin{array}{c}0.07087 \\
5 \\
\end{array}$ & $\begin{array}{c}- \\
0.03552 \\
\end{array}$ & $\begin{array}{c}0.11929 \\
8 \\
\end{array}$ & $\begin{array}{c}0.53523 \\
8 \\
\end{array}$ & -0.1853 & $\begin{array}{c}- \\
0.03135 \\
\end{array}$ & $\begin{array}{c}- \\
0.01887 \\
\end{array}$ & $\begin{array}{c}0.49002 \\
8 \\
\end{array}$ & $\begin{array}{c}- \\
0.02785 \\
\end{array}$ & $\begin{array}{c}0.01672 \\
2 \\
\end{array}$ \\
\hline $\begin{array}{c}1 \mathrm{Jul} \\
2011 \\
0\end{array}$ & $\begin{array}{c}0.63749 \\
1\end{array}$ & $\begin{array}{c}0.16563 \\
1\end{array}$ & 0.17866 & $\begin{array}{c}0.12179 \\
5\end{array}$ & $\begin{array}{c}1.68333 \\
3\end{array}$ & 0.26839 & $\begin{array}{c}0.44907 \\
7\end{array}$ & 2 & $\begin{array}{c}- \\
0.04589\end{array}$ & $\begin{array}{c}0.40507 \\
5\end{array}$ \\
\hline $\begin{array}{l}2 \text { Jan } \\
2010\end{array}$ & $\begin{array}{c}0.14860 \\
5\end{array}$ & $\begin{array}{c}0.21052 \\
6\end{array}$ & - & 0.31831 & - & $\begin{array}{c}- \\
0.00396\end{array}$ & $\begin{array}{c}0.82116 \\
2\end{array}$ & $\begin{array}{c}0.54761 \\
9\end{array}$ & $\begin{array}{c}- \\
0.01429\end{array}$ & $\begin{array}{c}0.08904 \\
8\end{array}$ \\
\hline $\begin{array}{l}1 \mathrm{Jul} \\
2009\end{array}$ & $\begin{array}{c}0.75482 \\
8\end{array}$ & $\begin{array}{c}0.63692 \\
3\end{array}$ & $\begin{array}{c}0.17792 \\
6\end{array}$ & $\begin{array}{c}0.16013 \\
1\end{array}$ & $\begin{array}{c}0.41910 \\
7\end{array}$ & 0.73468 & $\begin{array}{c}1.01462 \\
9\end{array}$ & $\begin{array}{c}0.13309 \\
4\end{array}$ & $\begin{array}{c}- \\
0.04372\end{array}$ & $\begin{array}{c}0.89341 \\
1\end{array}$ \\
\hline $\begin{array}{l}2 \text { Jan } \\
2009\end{array}$ & $\begin{array}{c}0.23486 \\
2\end{array}$ & $\begin{array}{c}0.10795 \\
5\end{array}$ & $\begin{array}{c}0.22764 \\
4\end{array}$ & $\begin{array}{c}- \\
0.03774\end{array}$ & $\begin{array}{c}0.39902 \\
4\end{array}$ & $\begin{array}{c}0.30781 \\
7\end{array}$ & $\begin{array}{c}0.50117 \\
6\end{array}$ & $\begin{array}{c}- \\
0.13687\end{array}$ & $\begin{array}{c}- \\
0.15862\end{array}$ & 0.02994 \\
\hline $\begin{array}{l}1 \mathrm{Jul} \\
2008\end{array}$ & $\begin{array}{c}- \\
0.35503\end{array}$ & $\begin{array}{c}- \\
0.22739\end{array}$ & $\begin{array}{c}- \\
0.37826\end{array}$ & $\begin{array}{c}- \\
0.16404\end{array}$ & $\begin{array}{c}- \\
0.56641\end{array}$ & $\begin{array}{c}- \\
0.24593\end{array}$ & $\begin{array}{c}- \\
0.28306\end{array}$ & $\begin{array}{c}- \\
0.30883 \\
\end{array}$ & $\begin{array}{c}- \\
0.07839 \\
\end{array}$ & $\begin{array}{c}- \\
0.38422\end{array}$ \\
\hline
\end{tabular}

Apabila return yang dihasilkan bernilai positif $(+)$ maka harga saham tersebut dinyatakan mengalami peningkatan. Kemudian, jika return yang dihasilkan bernilai negatif (-) maka kebalikan dari return positif, harga saham tersebut dinyatakan mengalami penurunan.

\section{E. Taxonomy}

Taxonomy merupakan teknik pengelompokan yang membantu memahami keanekaragaman pada suatu metode tertentu [4]. Pada pemilihan portofolio saham ini, taxonomy bertujuan untuk pengelompokan dataset saham pada sektor-sektor yang berbeda. Sehingga pada proses penggalian data dapat membentuk itemsets [5]. Untuk sektor yang berada di Indonesia diklasifikasikan ke dalam 9 sektor BEI. Sektor-sektor tersebut telah didasarkan pada klasifikasi indstri yang ditetapkan BEI yang disebut JASICA (Jakarta Stock Exchange 
Resi Annisa Nur et.al.

Pemilihan Portofolio Saham dengan...

Industrial Classification) [9]. Sektornya terdiri dari Pertanian, Aneka Industri, Property, Real Estate \& Konstruksi Bangunan, Pertambangan, Infrastruktur, Utilitas \& Transportasi, Keuangan, Industri Dasar \& Kimia, Industri Barang Konsumsi, Perdagangan, Jasa \& Investasi.

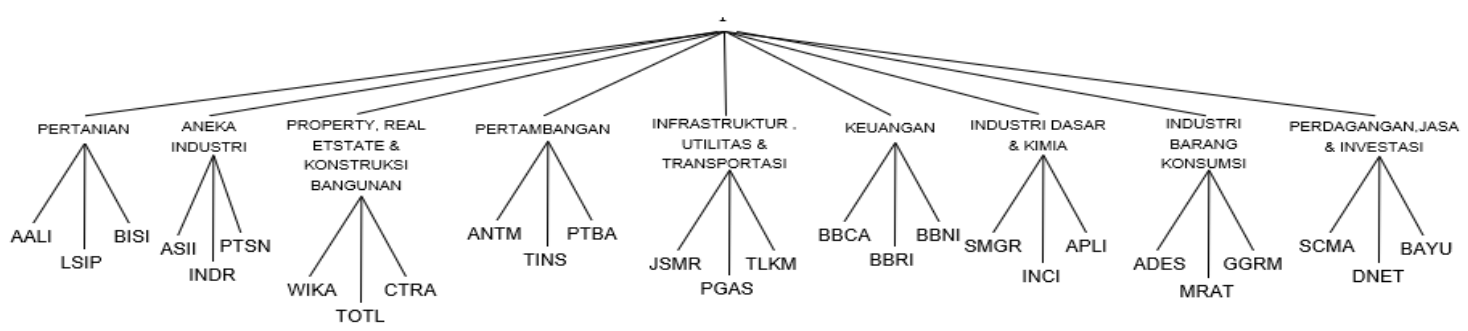

Gambar 1: Pengelompokan data saham pada sektor pasar.

\section{F. Weighted Itemsets Mining}

Weighted Itemsets Mining merupakan pencarian kombinasi pada data saham dengan menggunakan pendekatan berbasis itemsets untuk menemukan hubungan pada itemsets saham yang akan dipilih dengan memenuhi minimum return dan minimum diversifikasi. Itemsets terdiri dari kumpulan item yang terpilih Untuk menghitung frequent itemsets yaitu [3] :

$$
K S=\frac{\sum R_{t} \text { saham }}{\sum \text { record saham }}
$$

Keterangan :

KS $\quad$ = Rata-rata return saham yang terpilih.

$R_{t}$ saham $\quad=$ Jumlah dari nilai return pada setiap saham.

Record saham = Banyaknya record data saham yang digunakan.

Tabel II. Hasil perhitungan frequent itemsets dengan menggunakan minimum return $=5 \%$ dan minimum diversifikasi $=75 \%$.

\begin{tabular}{|c|c|c|c|c|c|}
\hline No. & $\begin{array}{c}\text { Saham } \\
\text { ke-1 }\end{array}$ & $\begin{array}{c}\text { Saham } \\
\text { ke-2 }\end{array}$ & $\begin{array}{c}\text { Saham } \\
\text { ke-3 }\end{array}$ & $\begin{array}{c}\text { Minimum } \\
\mu\end{array}$ & $\begin{array}{c}\text { Diversifikasi } \\
(\%)\end{array}$ \\
\hline 1. & 13 & 19 & 24 & 0.054 & 100 \\
\hline 2. & 13 & 23 & 27 & 0.0527 & 100 \\
\hline 3. & 18 & 19 & 27 & 0.0518 & 100 \\
\hline 4. & 19 & 23 & 27 & 0.0504 & 100 \\
\hline 5. & 4 & 24 & & 0.1494 & 100 \\
\hline 6. & 18 & 24 & & 0.1265 & 100 \\
\hline 7. & 13 & 18 & & 0.1224 & 100 \\
\hline 8. & 13 & 25 & & 0.1182 & 100 \\
\hline 9. & 4 & 18 & & 0.1169 & 100 \\
\hline 10. & 4 & 13 & & 0.1098 & 100 \\
\hline
\end{tabular}

Sebagai contoh, untuk mencari itemsets $\{18,24\}$ data yang digunakan ada pada Tabel I. Itemsets tersebut terdiri dari 2 saham yang berbeda. Berdasarkan Taxonomy, saham 18 merupakan persedian Keuangan dan saham 24 merupakan persedian Industri Barang Konsumsi. Untuk perhitungan data, telah ditetapkan minimum return 5\%. Maka untuk perhitungan yang dilakukan yaitu dengan mengambil yang paling minimum diatara dua saham tersebut. 
1.138529

9

$9=0.126503$

Jika hasil perhitungan tersebut tidak memenuhi syarat minimum return, maka itemsets tersebut tidak dipilih. Karena jika itemsets saham tersebut tetap dipilih, investor akan mengalami kerugian.

\section{G. Itemsets Diversification}

Diversifikasi adalah pembentukan suatu portofolio yang berada pada sektor yang berbeda [8] . Diversifikasi ini bertujuan untuk memastikan itemsets saham terdiversifikasi pada sektor-sektor yang berbeda dan memenuhi minimum diversifikasi. Pemilihan portofolio pada sektor yang berbeda tersebut akan mengurangi risiko investor dimasa depan [5]. Sebelum melakukan perhitungan diversifikasi harus ditetapkan minimum diversifikasi terlebih dahulu. Untuk menghitung diversifikasi portofolio saham yaitu [3] :

$$
\operatorname{div}(I, \tau)=\frac{|\sec (I)|}{|I|}
$$

Keterangan :

$\begin{array}{ll}I & =\text { Kumpulan dari itemsets saham. } \\ \tau & =\text { Taxonomy saham terhadap sektor. } \\ |\sec (I)| & =\text { Banyaknya sektor yang ada dalam itemsets } \\ |I| \quad=\text { Banyaknya saham pada itemsets. }\end{array}$

Sebagai contoh, sebelum mencari nilai diversifikasi harus menetapkan minimum diversifikasi terlebih dahulu. Untuk minimum diversifikasinya ditetapkan 75\%, setelah itu mencari nilai diversifikasi pada itemsets $\{13,19,24\}$ dan hasil diversifikasinya $100 \%$.

$$
\operatorname{div}(I, \tau)=\frac{1+1+1}{1+1+1}=\frac{3}{3} \times 100 \%=100 \%
$$

Jika hasil perhitungan yang diperoleh kurang dari minimum diversifikasi yang ditetapkan maka portofolio saham tersebut tidak akan dipilih. Kemudian setelah perhitungan diversifikasi selesai, semua itemsets saham yang diperoleh diurutkan berdasarkan itemsets terpanjang dan diversifkasi yang tertinggi. 
Resi Annisa Nur et.al.

\section{METODE PENELITIAN}

Pemilihan portofolio saham yang dilakukan yaitu, dengan menggunakan pendekatan Weighted Frequent Itemsets dan pengolahan data dilakukan pada perangkat lunak Matlab. Pemilihan portofolio saham yang dihasilkan didapat dari perhitungan itemsets dengan menggunakan minimum return yang berbeda. Pemilihan portofolio saham ini terdiri dari beberapa tahapan yang dapat dilihat pada Gambar 2.

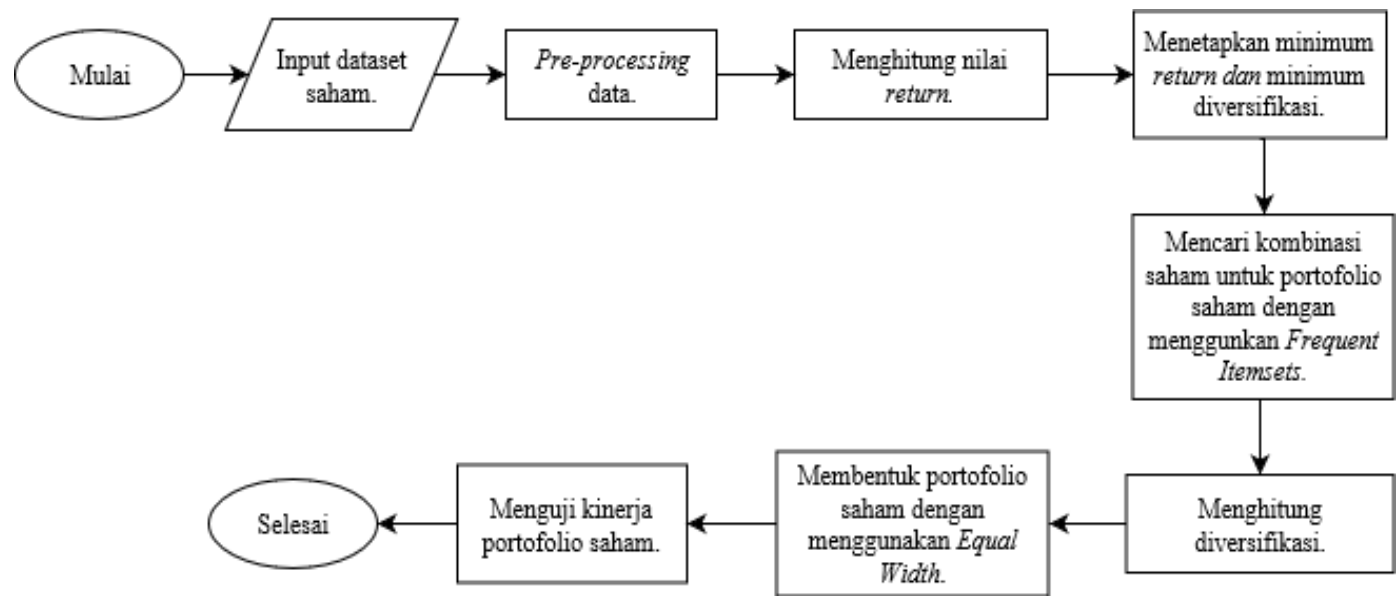

Gambar 2: Flowchart pemilihan portofolio saham.

\section{A. Input dataset saham}

Dataset saham yang digunakan untuk pengolahan data yaitu dataset saham yang didapatkan dari Yahoo! Finance (YahooFinance, 2018). Dataset saham yang digunakan dari Tanggal 1 Januari 2008 hingga 31 Desember 2017 setiap 6 bulan sebanyak 27 data yang berada pada sektor yang berbeda. Dataset tersebut dapat dilihat pada Tabel III.

Tabel III. Dataset saham yang digunakan.

\begin{tabular}{|l|l|l|}
\hline No. & \multicolumn{1}{|c|}{ Nama Saham } & \multicolumn{1}{|c|}{ Sektor } \\
\hline 1. & AALI (Astra Argo Lestari Tbk) & Pertanian \\
\hline 2. & LSIP (PP London Sumatera Indonesia Tbk) & Pertanian \\
\hline 3. & BISI (Bisi International Tbk) & Pertanian \\
\hline 4. & ASII (Astra International Tbk) & Aneka Industri \\
\hline 5. & INDR (Indo Rama Synthetic Tbk) & Aneka Industri \\
\hline 6. & PTSN (Sat Nusa Persada Tbk) & Aneka Industri \\
\hline 7. & WIKA (Wijaya Karya Persero Tbk) & Property, Real Estate \& Konstruksi Bangunan \\
\hline 8. & TOTL (Total Bangun Persada Tbk) & Property, Real Estate \& Konstruksi Bangunan \\
\hline 9. & CTRA (Ciputra Development Tbk) & Property, Real Estate \& Konstruksi Bangunan \\
\hline 10. & ANTM (Aneka Tambang Tbk) & Pertambangan \\
\hline 11. & TINS (Timah Persero Tbk) & Pertambangan \\
\hline 12. & PTBA (Tambang Batubara Bukit Asam Tbk) & Pertambangan \\
\hline 13. & JSMR (Jasa Marga (Persero) Tbk) & Infrastruktur, Utilitas \& Transportasi \\
\hline 14. & PTBA (Perusahaan Gas Negara (Persero) Tbk) & Infrastruktur, Utilitas \& Transportasi \\
\hline 15. & TLKM (Telekomunikasi Indonesia Tbk) & Infrastruktur, Utilitas \& Transportasi \\
\hline 16. & BBCA (Bank Central Asia Tbk) & Keuangan \\
\hline 17. & BBRI ( Bank Rakyat Indonesia (P) Tbk) & Keuangan \\
\hline 18. & BBNI (Bank Negara Indonesia (P) Tbk) & Keuangan \\
\hline 19. & SMGR (Semen Indonesia (P) Tbk d.h Semen & Industri Dasar \& Kimia \\
\hline 20. & Gresik) & \\
\hline
\end{tabular}




\begin{tabular}{|l|l|l|}
\hline 21. & APLI (Asiaplast Industries Tbk) & Industri Dasar \& Kimia \\
\hline 22. & ADES (Akasha Wira International Tbk) & Industri Barang Konsumsi \\
\hline 23. & MRAT (Mustika Ratu Tbk) & Industri Barang Konsumsi \\
\hline 24. & GGRM (Gudang Garam Tbk) & Industri Barang Konsumsi \\
\hline 25. & SCMA (Surya Citra Medika Tbk) & Perdagangan, Jasa \& Investasi \\
\hline 26. & DNET (Indontel Makmur International Tbk) & Perdagangan, Jasa \& Investasi \\
\hline 27. & BAYU (Bayu Buana Tbk) & Perdagangan, Jasa \& Investasi \\
\hline
\end{tabular}

\section{B. Pre-processing data}

Dataset saham yang digunakan pada penelitian ini yaitu diambil dari nilai rata-rata 6 bulan. Pada saat data akan diproses, data tersebut ada yang memiliki missing value. Maka, data yang memiliki missing value di preprocessing terlebih dahulu supaya data tersebut dapat diproses saat diolah.

\section{Menghitung return saham}

Proses perhitungan return saham yang dilakukan yaitu dari harga sekarang dikurangi harga kemarin dan dibagi dengan harga kemarin. Dapat dilihat pada Tabel IV untuk daftar harga saham sebelum return saham dihitung. Kemudian untuk hasil perhitungan return saham dapat dilihat pada Tabel V.

Tabel IV. Daftar harga saham.

\begin{tabular}{|c|c|c|}
\hline Tahun & AALI & LSIP \\
\hline 1 Jul 2017 & 14429.17 & 1419.167 \\
\hline 2 Jan 2017 & 14837.5 & 1463.333 \\
\hline 1 Jul 2016 & 15716.67 & 1596.667 \\
\hline
\end{tabular}

Tabel V. Daftar return saham

\begin{tabular}{|c|c|c|}
\hline Tahun & AALI & LSIP \\
\hline 1 Jul 2017 & -0.02752 & -0.03018 \\
\hline 2 Jan 2017 & -0.05594 & -0.08351 \\
\hline 1 Jul 2016 & 0.047563 & 0.048369 \\
\hline
\end{tabular}

D. Mengelompokan dataset saham

Pada dataset saham yang digunakan untuk proses penelitian dikelompokan pada sektor-sektor pasar. Dari 27 data yang dipakai akan dikelompokan pada 9 sektor saham. Sektor tersebut yaitu Pertanian, Aneka Industri, Property Real Estate \& Konstruksi Bangunan, Pertambangan, Infrastruktur Utilitas \& Transportasi, Keuangan, Industri Dasar \& Kimia, Industri Barang Konsumsi dan Perdangan Jasa \& Investasi.

\section{E. Menghitung dataset saham}

Proses perhitungan dataset saham yang akan dicari kombinasi dengan Frequent Itemsets dari setiap iterasinya yaitu dengan cara menentukan minimum return terlebih dahulu. Pada iterasi pertama hanya melakukan perhitungan dengan mencari nilai rata-rata dari saham. Kemudian data yang memenuhi return akan masuk pada iterasi selanjutnya. Pada iterasi selanjutnya ada sedikit perbedaan, yaitu pada proses perhitungan dipilih nilai yang paling minimum diantara kedua saham atau lebih kemudian dihitung rataratanya.

\section{F. Menghitung diversifikasi portofolio}

Pada perhitungan diversifikasi portofolio harus menentukan minimum diversifikasi terlebih dahulu. Untuk mengetahui diversifikasi pada portofolio saham yang dipilih dapat dilihat dari sektornya. Portofolio saham yang diperoleh diurutkan berdasarkan hasil yang paling tinggi. Semakin baik nilai diversifikasi, maka tingkat resiko semakin kecil.

G. Membentuk portofolio saham 
Resi AnNisa Nur ET.AL.

Pemilihan Portofolio Saham dengan...

Setelah mendapatkan portofolio saham yang memenuhi minimum return dan minimum diversifikasi, portofolio terebut dibentuk dengan memberikan bobot terhadap masing-masing saham yang ada pada portofolio saham. Untuk proses pembentukan portofolio saham menggunakan equal width. Jadi bobot yang diberikan dibagi rata sesuai dengan jumlah saham yang terdapat pada portofolio saham.

\section{H. Menguji kinerja portofolio saham}

Setelah mendapatkan itemsets terpanjang yang memenuhi minimum return dan minimum diversifikasi maka data tersebut diuji sesuai dengan masing-masing skenario dan sesuai dengan minimum return yang digunakan. Skenario yang digunakan pada pengujian ini ada 2 skenario. Skenario 1, saham yang digunkan untuk investasi tidak berubah. Skenario 2, saham yang digunakan untuk investasi berubah sesuai dengan inputan data saham. Setelah itu dilihat perbandingan hasil dari minimum return yang berbeda.

\section{Hasil}

Hasil dari semua proses diatas, untuk portofolio yang dipilih memiliki itemsets yang terpanjang yang memenuhi minimum return dan portofolio saham tersebut berada pada sektor-sektor yang berbeda.

\section{HASIL DAN DISKUSI}

Berdasarkan dari hasil pengolahan data yang telah dilakukan dengan melakukan perhitungan frequent itemsets, diversifikasi portofolio dengan menggunakan minimum return $5 \%$ dan minimum diversifikasi $75 \%$ maka hasil yang diperoleh yaitu pada Tabel VI.

Tabel VI. Hasil perhitungan frequent itemsets dan diversifikasi portofolio.

\begin{tabular}{|c|c|c|c|c|c|c|c|}
\hline No. & $\begin{array}{c}\text { Saham } \\
\text { ke-1 }\end{array}$ & $\begin{array}{c}\text { Saham } \\
\text { ke-2 }\end{array}$ & $\begin{array}{c}\text { Saham } \\
\text { ke-3 }\end{array}$ & $\begin{array}{c}\text { Saham } \\
\text { ke-4 }\end{array}$ & $\begin{array}{c}\text { Saham } \\
\text { ke-5 }\end{array}$ & Minimum $\mu$ & Diversifikasi(\%) \\
\hline 1. & 4 & 18 & 23 & 24 & 27 & 0.0527 & 80 \\
\hline 2. & 4 & 13 & 18 & 23 & 24 & 0.0504 & 80 \\
\hline 3. & 4 & 18 & 23 & 24 & & 0.0713 & 15 \\
\hline 4. & 4 & 18 & 24 & 27 & & 0.0668 & 100 \\
\hline 5. & 4 & 13 & 18 & 24 & & 0.0649 & 100 \\
\hline 6. & 4 & 18 & 19 & 24 & & 0.0648 & 75 \\
\hline 7. & 4 & 13 & 23 & 24 & & 0.0577 & 100 \\
\hline 8. & 4 & 18 & 23 & 27 & & 0.0571 & 75 \\
\hline 9. & 4 & 23 & 24 & 27 & & 0.0571 & 100 \\
\hline 10. & 13 & 18 & 24 & 27 & & 0.0569 & 100 \\
\hline 11. & 4 & 13 & 18 & 19 & & 0.0557 & 100 \\
\hline 12. & 4 & 13 & 18 & 27 & & 0.0552 & 75 \\
\hline 13. & 4 & 13 & 18 & 23 & & 0.0548 & 100 \\
\hline 14. & 18 & 23 & 24 & 27 & & 0.0536 & 100 \\
\hline 15. & 4 & 13 & 19 & 24 & & 0.0526 & 75 \\
\hline 16. & 4 & 18 & 19 & 27 & & 0.0518 & 100 \\
\hline 17. & 13 & 18 & 23 & 24 & & 0.0513 & 75 \\
\hline 18. & 4 & 13 & 19 & 27 & & 0.0503 & 100 \\
\hline 19. & 4 & 19 & 23 & 24 & & 0.0501 & 0.0981 \\
\hline 20. & 4 & 18 & 24 & & & & \\
\hline
\end{tabular}




\section{A. Hasil Pengujian Data}

Dalam melakukan pemilihan portofolio saham dilakukan dengan menggunakan beberapa skenario pengujian data dan berdasarkan penggunaaan minimum return yang berbeda. Minimum return yang digunakan yaitu 3\%, 4\% dan 5\%. Untuk skenario yang digunakan hanya ada 2 , yaitu :

\section{B. Skenario 1}

Pada skenario 1 ini, untuk proses pembentukan portofolio yang dilakukan yaitu mengacu pada hasil perhitungan yang dilakukan pada data acuan dimulai dari 1 Januari 2008 sampai 2012. Jadi untuk portofolio saham yang diuji selanjutnya pada setiap 6 bulan berikutnya pembentukan portofolio saham tidak berubah berdasarkan saham yang didapatkan pada 1 Januari 2008 sampai 2012, yaitu ada 5 saham yang terpilih. Kemudian portofolio saham tersebut diuji menggunakan minimum return yang berbeda. Untuk hasil yang diperoleh dari pengujian data dengan menggunakan minimum return 3\% dan minimum diversifikasi $75 \%$ dapat dilihat pada Tabel VII.

Tabel VII. Hasil pengujian skenario 1 dengan menggunakan minimum return 3\%.

\begin{tabular}{|c|c|c|c|c|c|c|c|c|c|c|}
\hline Tahun & $\begin{array}{c}\text { Saham } \\
\text { ke-1 }\end{array}$ & $\begin{array}{c}\text { Saham } \\
\text { ke-2 }\end{array}$ & $\begin{array}{c}\text { Saham } \\
\text { ke-3 }\end{array}$ & $\begin{array}{c}\text { Saham } \\
\text { ke-4 }\end{array}$ & $\begin{array}{c}\text { Saham } \\
\text { ke-5 }\end{array}$ & $\begin{array}{c}\text { Minimum } \\
\mu\end{array}$ & $\begin{array}{c}\text { Diversifikasi } \\
(\%)\end{array}$ & Bobot & $\begin{array}{c}\text { Return } \\
\text { Portofolio }\end{array}$ & $\begin{array}{c}\text { Nilai } \\
\text { Portofolio }\end{array}$ \\
\hline $\begin{array}{c}\text { 2008- } \\
\text { 2012 }\end{array}$ & 4 & 18 & 23 & 24 & 27 & 0.0527 & 80 & 0.2 & 0.1826 & 1 \\
\hline $\begin{array}{c}\text { 2 Jan } \\
\text { 2013 }\end{array}$ & 4 & 18 & 23 & 24 & 27 & & 80 & 0.2 & 0.1101 & 1.1101 \\
\hline $\begin{array}{l}\text { 1 Jul } \\
\text { 2013 }\end{array}$ & 4 & 18 & 23 & 24 & 27 & & 80 & 0.2 & -0.1242 & 0.97222558 \\
\hline $\begin{array}{c}\text { 2 Jan } \\
\text { 2014 }\end{array}$ & 4 & 18 & 23 & 24 & 27 & & 80 & 0.2 & 0.177 & 1.144309508 \\
\hline $\begin{array}{l}\text { 1 Jul } \\
\text { 2014 }\end{array}$ & 4 & 18 & 23 & 24 & 27 & & 80 & 0.2 & 0.2027 & 1.144309508 \\
\hline $\begin{array}{c}\text { 2 Jan } \\
\text { 2015 }\end{array}$ & 4 & 18 & 23 & 24 & 27 & & 80 & 0.2 & -0.0391 & 1.322449238 \\
\hline $\begin{array}{c}\text { 1 Jul } \\
\text { 2015 }\end{array}$ & 4 & 18 & 23 & 24 & 27 & & 80 & 0.2 & -0.1617 & 1.108609196 \\
\hline $\begin{array}{l}\text { 2 Jan } \\
\text { 2016 }\end{array}$ & 4 & 18 & 23 & 24 & 27 & & 80 & 0.2 & 0.1773 & 1.305165607 \\
\hline $\begin{array}{c}\text { 1 Jul } \\
\text { 2016 }\end{array}$ & 4 & 18 & 23 & 24 & 27 & & 80 & 0.2 & 0.02 & 1.331268919 \\
\hline $\begin{array}{l}\text { 2 Jan } \\
\text { 2017 }\end{array}$ & 4 & 18 & 23 & 24 & 27 & & 80 & 0.2 & 0.0357 & 1.378795219 \\
\hline $\begin{array}{l}\text { 1 Jul } \\
\text { 2017 }\end{array}$ & 4 & 18 & 23 & 24 & 27 & & 80 & 0.2 & 0.1066 & 1.52577479 \\
\hline
\end{tabular}

\section{Skenario 2}

Pada skenario 2 ini, proses pembentukan portofolionya berbeda dengan skenario 1. Jika skenario 1 melakukan pembentukan portofolio yang sama atau portofolio saham yang dibentuk tidak diubah dengan mengacu pada portofolio saham yang didapatkan. Untuk skenario 2 pembentukan portofolio yang dilakukan yaitu, portofolio saham berubah sesuai dengan inputan data yang masuk selama 6 bulan berikutnya. Maka hasil portofolio saham yang didapatkan akan berbeda setiap inputan data selama 6 bulan. Pada 1 Januari 2008 sampai 2012 saham yang terpilih 5 dan pada 1 Juli 2017 hanya 2 saham saja yang terpilih. Kemudian untuk pengujian portofolio saham ini menggunakan minimum return yang berbeda juga. Hasil pengujian diperoleh dengan menggunkan minimum return 3\% dapat dilihat pada Tabel VIII. 
Resi Annisa Nur et.al.

Pemilihan Portofolio Saham dengan...

Tabel VIII. Hasil pengujian skenario 2 dengan menggunakan minimum return 3\%.

\begin{tabular}{|c|c|c|c|c|c|c|c|c|c|c|}
\hline Tahun & $\begin{array}{c}\text { Saham } \\
\text { ke-1 }\end{array}$ & $\begin{array}{c}\text { Saham } \\
\text { ke-2 }\end{array}$ & $\begin{array}{c}\text { Saham } \\
\text { ke-3 }\end{array}$ & $\begin{array}{c}\text { Saham } \\
\text { ke-4 }\end{array}$ & $\begin{array}{c}\text { Saham } \\
\text { ke-5 }\end{array}$ & $\begin{array}{c}\text { Minimum } \\
\mu\end{array}$ & $\begin{array}{c}\text { Diversifikasi } \\
(\%)\end{array}$ & Bobot & $\begin{array}{c}\text { Return } \\
\text { Portofolio }\end{array}$ & $\begin{array}{c}\text { Nilai } \\
\text { Portofolio }\end{array}$ \\
\hline $\begin{array}{c}2008- \\
\text { 2012 }\end{array}$ & 4 & 18 & 23 & 24 & 27 & 0.0527 & 80 & 0.2 & 0.1826 & 1 \\
\hline $\begin{array}{c}\text { 2 Jan } \\
\text { 2013 }\end{array}$ & 4 & 18 & 23 & 24 & 27 & 0.0918 & 80 & 0.2 & 0.2303 & 1.2303 \\
\hline $\begin{array}{c}\text { 1 Jul } \\
\text { 2013 }\end{array}$ & 4 & 18 & 23 & 24 & 27 & 0.0627 & 80 & 0.2 & 0.1889 & 1.4627 \\
\hline $\begin{array}{c}\text { 2 Jan } \\
\text { 2014 }\end{array}$ & 7 & 13 & 18 & 25 & 27 & 0.0344 & 80 & 0.2 & 0.2462 & 1.8228 \\
\hline $\begin{array}{c}\text { 1 Jul } \\
\text { 2014 }\end{array}$ & 7 & 13 & 18 & 25 & 27 & 0.0415 & 80 & 0.2 & 0.2609 & 2.2984 \\
\hline $\begin{array}{c}\text { 2 Jan } \\
\text { 2015 }\end{array}$ & 9 & 25 & & & & 0.0988 & 100 & 0.5 & 0.2097 & 2.7804 \\
\hline $\begin{array}{l}\text { 1 Jul } \\
\text { 2015 }\end{array}$ & 9 & 25 & & & & 0.0741 & 100 & 0.5 & 0.1655 & 3.2405 \\
\hline $\begin{array}{c}\text { 2 Jan } \\
\text { 2016 }\end{array}$ & 15 & 27 & & & & 0.0889 & 100 & 0.5 & 0.1622 & 3.7661 \\
\hline $\begin{array}{l}\text { 1 Jul } \\
\text { 2016 }\end{array}$ & 15 & 27 & & & & 0.0683 & 100 & 0.5 & 0.1554 & 4.3514 \\
\hline $\begin{array}{l}\text { 2 Jan } \\
\text { 2017 }\end{array}$ & 15 & 16 & & & & 0.0538 & 100 & 0.5 & 0.0925 & 4.7539 \\
\hline $\begin{array}{l}\text { 1 Jul } \\
\text { 2017 }\end{array}$ & 15 & 16 & & & & 0.0381 & 100 & 0.5 & 0.0802 & 5.1352 \\
\hline
\end{tabular}

D. Analisis Hasil Pengujian

Berdasarkan dari hasil pengujian dataset saham dengan menggunakan skenario 1, pembentukan portofolio saham dengan menetapkan return yang berbeda yaitu 3\%, 4\%, 5\%, diversifikasi $75 \%$ dan investasi pertama sebesar 1 . Hasil yang diperoleh memiliki kesamaan yaitu, untuk portofolio saham yang dihasilkan ASII, BBNI, MRAT, GGRM, BAYU dengan nilai portofolio 1.52577479 dan diversifikasi $80 \%$. Jadi return yang dihasilkan selama 5 tahun dengan menggunakan data setiap 6 bulan sama, yaitu 0.52577479 . Kemudian, setelah itu dilakukan perbandingan menggunakan IHSG (Indeks Harga Saham Gabungan), dimana IHSG untuk melihat rata-rata harga saham saat ini. Data yang digunakan untuk melakukan perbandingan yaitu data setiap 6 bulan untuk grafik dapat dilihat pada Gambar 3. 


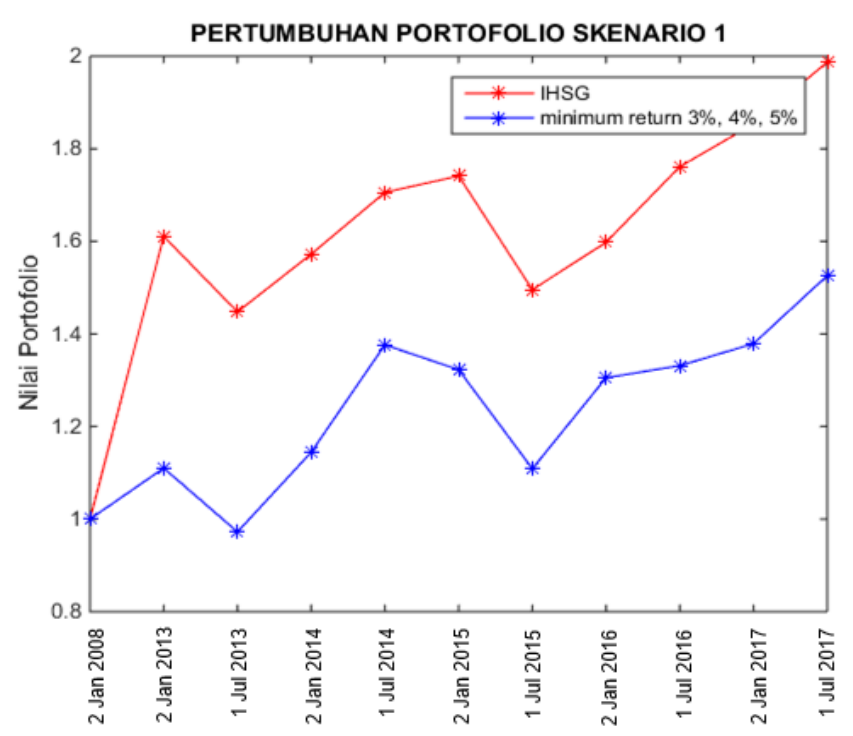

Gambar 3: Grafik pertumbuhan portofolio skenario 1 dengan minimum return 3\%.

Berdasarkan dari hasil pengujian dataset saham dengan menggunakan skenario 2, pembentukan portofolio saham dengan menetapkan return yang berbeda yaitu 3\%, 4\%,5\%, diversifikasi $75 \%$ dan investasi pertama sebesar 1 . Hasil pembentukan portofolio saham yang didapatkan berbeda, yang dapat dilihat pada Tabel VII. Kemudian untuk nilai portofolio yang didapatkan dapat dilihat pada Gambar 4. Pada saat menetepakan minimum return 3\%, 4\% dan 5\% nilai portofolio selalu meningkat, untuk return yang didapatkan berbeda. Semakin besar minimum return yang ditetapkan, maka semakin besar return yang didapatkan.

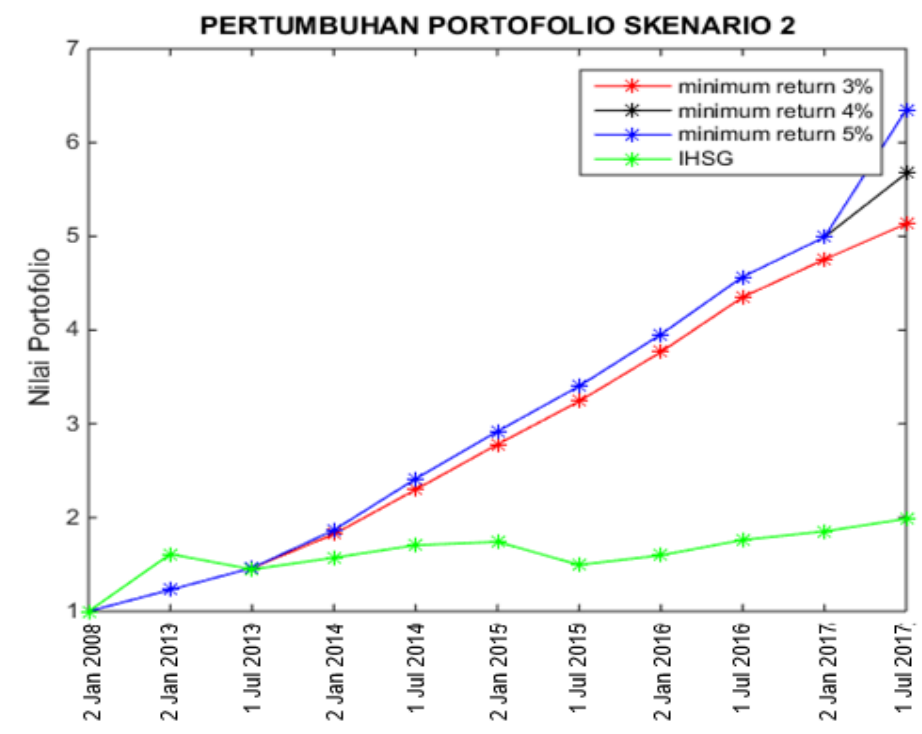

Gambar 4: Grafik pertumbuhan portofolio skenario 2 dengan minimum return 3\%.

Maka, untuk pemilihan portofolio saham dengan menggunakan 2 skenario yaitu skenario 1 dan skenario 2 dengan menetapkan return yang berbeda yaitu 3\%, 4\%, 5\%, diversifikasi 75\% dan investasi pertama sebesar 
Resi Annisa Nur et.al.

Pemilihan Portofolio Saham dengan...

1. Untuk hasil yang didapatkan dari skenario 1 dan skenario 2 berbeda. Perbedaan hasil tersebut dapat dilihat pada portofolio saham yang didapatkan, return portofolio dan yang pasti dapat dilihat pada nilai portofolio saham. Untuk skenario 1 pembentukan portofolio sahamnya tetap tidak berubah. Selain itu, untuk grafik nilai portofolio mengalami kenaikan dan penurunan. Kemudian untuk skenario 2 pembentukan portofolio saham berubah, hasil yang diperoleh pada tahun 2017 di 6 bulan terakhir pembentukan portofolio saham yang didapatkan hanya 1 saham saja. Setelah itu, dilihat dari return portofolio saham return yang didapatkan mengalami naik turun. Jadi, jika investor memilih skenario 1 return yang didapatkan kecil dengan pembentukan portofolio yang tidak berubah. Kemdian jika salah satu saham rugi maka masih ada saham lain yang menghasilkan keuntungan. Untuk skenario 2 return yang dihasilkan lebih besar dari skenario 1 dengan pembentukan portofolio saham yang berubah. Pada hasil perhitungan minimum return $5 \%$ portofolio saham yang diperoleh hanya 1 saham saja. Jadi, jika saham tersebut turun maka kerugian yang didapatkan sangat besar.

\section{KESIMPULAN}

Berdasarkan penelitian yang dilakukan dalam melakukan pemilihan portofolio saham dengan menggunakan pendekatan Weighted Frequent Itemsests yaitu :

1. Dilihat dari grafik hasil pengujian skenario 1 menunjukan bahwa pembentukan portofolio saham statis dan saat dilakukan perbandingan dengan IHSG, hasil kinerjanya berada dibawah rata-rata harga saham IHSG.

2. Dilihat dari grafik hasil pengujian skenario 2 menunjukan bahwa pembentukan portofolio saham dinamis dan saat dilakukan perbandingan dengan IHSG, hasil kinerjanya berada diatas rata-rata harga saham IHSG.

\section{PUSTAKA}

[1] Zalmi Zubir, Manajemen Portofolio Penerapannya dalam Investasi Saham, Jakarta: Salemba Empat, 2011.Hal.2.

[2] Hung Long Nguyen, "An Efficient Algorithm for Mining Weighted Frequent Itemsets Using Adaptive Weights", Faculty of Economic

Information System, Vietnam Commercial University (VCU), 2015. means of weighted frequent itemsets", Dipartimento di Automatica e Informatica, Politecnico di Torino, Corso Duca degli Abruzzi 24, 10129, Torino, Italy : Elsevier, 2017.

[3] Elena Baralis, Luca Cagliero, Paolo Garza, "Planning stock portfolios by means of weighted frequent itemsets", Dipartimento di Automatica e Informatika, Politecnico di Torino, Corso Duca degli Abruzzi 24, 10129, Torino, Italy : Elsivier,2017.

[4] Oded Maimon, Lior Rokach, The Data Mining and Knowlegde Discovery Handbook.Tel-Aviv University, Israel: Springer, 2005.Hal.6.

[5] Irham Fahmi, Pengantar Teori Portofolio dan Analisis Investasi, Bandung: Alfabeta, 2015.Hal.58.

[6] Jeannette M. de Graaf a , Walter A. Kosters a, Jeroen J.W. Witteman a, Interesting Association Rules in Multiple Taxonomies, Universiteit Leiden P.O. Box 9512, 2300 RA Leiden, The Netherlands.

[7] Donny Mitra Virgiawan dan Imam Mukhlash, "Aplikasi Association Rule Mining Untuk menemukan Pola Pada Data Nilai Mahasiswa

Matematika ITS Donny”, Matematika, Jurnal Sains dan seni pomits. Vol. 1, No. 1, (2013) 1-6, 2013.

[8] Tyas Auruma S. "Diversifikasi investasi saham : Perbandingan risiko total portofolio melaui diversifikasi domestik dan Internasional", Jurnal Manajemen Teori dan Terapan, 2013.

[9] Sektor BEI (Bursa Efek Indonesia), "Saham OK”, [Online]. Available : https://www.sahamok.com/emiten/sektor-bei/ [Diakses 10 12 $2017]$.

[10] Marek Capinski, Tomasz Zastawniak, Mathematics for Finance: An Introduction to financial Engineering, London, Berlin, Heidelberg,

New York, Hongkong, Milan, Paris, Tokyo: Spriger, 2003.Hal.49. 